\title{
The New Union Flag Project
}

The New Union Flag project, by the artist Gil Mualem-Doron, reimagines the Union Flag in a way that reflects the changing society in which we live, acknowledging and celebrating the communities that have contributed to the UK's cultural legacy. Re-created with fabric designs from all over the world, the New Union Flag transforms the traditional Union Jack from an archetype of uniformity into a dynamic and celebratory on-going performance of diversity. While it appears on this book's cover as a static image, it is in fact a constantly evolving entity.

From 2015, when it was first exhibited at Peckham Platform, the New Union Flag has evolved every few months with the contributions of participants from various national and ethnic backgrounds. For five years now, it has engaged tens of thousands of people through gallery exhibitions (Turner Contemporary, Tate Modern, the Southbank Centre, People's History Museum - Manchester, Liverpool Museum), numerous cultural events, school visits, festivals, rallies, and workshops.

The New Union Flag project also includes portraits of people who would like to see it adopted as the national flag, as well as others who don't, and recordings of conversations with them. The New Union Flag project is an ongoing project, and, pending funding, another national tour is planned for 2021.

More information about the project, short films, and photography can be found at: www.http://gildoron.co.uk 
Rachael Gilmour - 9781526108852

Downloaded from manchesterhive.com at $04 / 26 / 2023$ 12:19:43PM 